Most glaring is the sexism of that system. When female scientists appear in the book they are "Young ladies" or "An attractive young lady'. You will look in vain for reference to "Elegant gentlemen" joining the expedition and the text is definitely without "Pretty young men". During Worthington's years at the Fresh Water Biological station at Windermere, a woman started a career there whose work seems to many of us to be perhaps the most notable ever to have come from that laboratory; but her arrival is introduced with the information that "We put her on to . . .", a phrase not used for the work of any man. Worthington has honest pleasure in recounting that this woman is now a Fellow of the Royal Society. A cynic might note that this richly deserved honour came to her only after the first light airs of social change in England made some acknowledgement of women necessary. She never was granted chairs of national committees or a powerful professorship, unlike the males of her scientific cohort.

With equal strength the failure of the Imperial British to exploit their African colonies comes through. Before Worthington's generation little seems to have been done, even to survey or catalogue resources, a point made so forcibly by Correlli Barnett in The Collapse of British Power (Eyre Methuen, 1972). Africa for the British was a place to be governed, and the extraction of wealth was sufficient if the resulting taxes paid for the government. The men sent to govern thought of resources for hunting and fishing, even to the extent of a mischievous planting of trout in upland rivers, not of exploitation for their own or their subjects wealth. Worthington recounts how this attitude changed only with the advent of awareness of the value of the countryside about to be handed back to its native peoples.

If the system's warts show through in Worthington's picture, it is yet clear that its picked man deserved the trust invested in him. In groping for ecological thought he was ahead of his time, already thinking in an Eltonian way about the ecosystems of African lakes in the year that C.S. Elton published Animal Ecology, the first modern textbook of ecology (Sidgwick, 1927). Some of the ecological assertions in the book are open to challenge, and there is some unconscious revisionism, as when he talks of his early African work in the language of energy flow, a concept then still ten years off. But he foresaw more clearly than most the need to plan for development in what now would be called an ecological way. Doubtless many of the last decisions of colonial governors were the wiser as a result of his passion. And yet it may be that this short statement of his working life, in telling of those vanished times, will be of more lasting benefit.

Paul A. Colinvaux is a Professor in the Department of Zoology at The Ohio State University, Columbus, Ohio.

\section{In the blood: the evolution of mankind}

\section{C.O. Carter}

Blood Relations: Blood Groups and Anthropology.

By A. E. Mourant.

Oxford University Press: 1983. Pp.146. £15, \$20.50.

MANKIND has long been interested in the variability of his own species. The first classifications were inevitably based on physical features such as skin colour, hair colour and form, skeletal shape and facial features. These made possible the broad distinction between the Caucasoids in Europe, North Africa, south-west Asia and India, the Mongoloids in the Far East and south-east Asia, and the Negroids in Africa south of the Sahara.

But external characters were not altogether satisfactory; their inheritance is complex and some characters are shared by unrelated populations as a result of exposure to similar selective forces, for example the very dark skin found in parts of Africa, India and Melanesia. So when the $\mathrm{ABO}$ blood groups were discovered in 1900 , and their Mendelian inheritance demonstrated in 1910 (though not fully elucidated until 1924), it was natural that analysis of their distribution should attract the attention of anthropologists. The first contribution was by the Hirszfelds at the end of the First World War. They were able to demonstrate the relatively high $\mathbf{A}$ frequency in Europeans and the increasing frequency of B as one moved towards eastern Europe and western and central Asia. Since then a mass of data has been collected worldwide for the ABO groups, and to a lesser extent for more recently discovered blood groups, plasma proteins, red cell enzymes and variants of the $\beta$-chain of haemoglobin.

Since the end of the Second World War, A.E. Mourant and his colleagues have systematically organized the collection of such data and published their findings and those of other workers in detail. In this short book, Dr Mourant has attempted a synthesis of all the work of preceding years.

The origins of the differences in gene frequency between populations are mutation (the original source of diversity but a rare event), natural selection and founder effect and drift. Mutation is slow to produce change; natural selection may be relatively quick; founder effect and drift operate especially when populations are small. As to the blood genes themselves, the frequencies of those for the $A B O$ groups are relatively labile, of those for the MNS and Rhesus factors more stable. Isolated populations tend to be high in $\mathrm{O}$, probably as a result of the loss of A and B fetuses of $\mathrm{O}$ mothers when not counteracted by selective advantage of the $A$ and $B$ genes.

Mourant considers each continent in turn. Africa was the only home of man until about a million years ago, when at the Homo erectus stage men and women migrated to Europe, the Far East and Indonesia. Modern man, Homo sapiens sapiens, originating probably in western Asia, spread worldwide (including Australia but perhaps later to America) some 40,000 years ago, replacing and probably interbreeding with local lessdeveloped varieties of man. The Sahara desert, however, became a formidable barrier to migration. It is therefore intelligible that in Africa south of the desert there are a number of "marker" genes which are rare elsewhere. These include the $S^{\mathrm{u}}$ allele and the Henshaw gene of the MNS system, the $c D e$ haplotype of the Rhesus system, the $J s^{\text {a }}$ gene of the Kell system, the $\mathrm{Fy}^{4}$ allele of the Duffy system and the gene for sickle-cell haemoglobin. The selective force for the latter two is malaria; homozygotes for the $\mathrm{Fy}^{4}$ gene are almost totally resistant to Plasmodium vivex and heterozygotes for the sickle-cell gene have considerable resistance to Plasmodium falciparum.

Turning to Eurasia and Australasia, Caucasoids and Mongoloids resemble each other more than either do the Negroids. Mongoloids have less $k$, less $d$ and a low but consistent frequency of the $D t^{a}$ gene of the Diego system, which is virtually absent in Caucasoids. Dr Mourant also discusses the contribution of the blood groups to several of the'smaller scale questions in this area: the origin of the Basques, the Jews, the Gypsies, the Polynesians and the Ainu, and the relationship of the Australian aboriginals to tribal groups in south-west India. In addition he describes what little further is known about the relationships of blood group to susceptibility to specific diseases.

Blood Relations is an admirably clear exposition of what may be learnt from the distribution of these nuclear genes. There is much we still do not know, however; for instance Dr Mourant notes that the polymorphism of the histocompatibility genes has been studied so far only in developed countries. But here, a powerful new technique is emerging, which is outside the scope of his book. This is the study of the distribution of the polymorphisms for restriction enzyme fragments of nonnuclear (mitochondrial) DNA. This DNA is probably transmitted only by the ovum, so is inherited entirely through the maternal line and the lineage is not obscured by Mendelian segregation.

Cedric Carter died shortly before the publication of this review. He was Head of the Medical Research Council's Clinical Genetics Unit at the Institute of Child Health, London, becoming Emeritus Professor in the University of London upon retirement. Among his works was Human Heredity (Pelican, 1962). 